\title{
Sümela Manastırı Kültürel Mirası için Tanımlanması Gereken Miras Alanı ve Tampon Bölgesine Yönelik Öneriler
}

\author{
Veysel Özbey \\ Çukurova Üniversitesi, Fen Bilimleri Enstitüsü \\ Mimarlık Ana Bilim Dalı, Doktora Öğrencisi \\ veyselozbey@gmail.com
}

Öz

UNESCO Dünya Kültürel ve Doğal Mirasın Korunmasına Dair Sözleşme’ye taraf devletler, UNESCO Dünya Miras Listesi'ne tanımlamak istedikleri miraslarını kendi UNESCO geçici listelerine yazdırmakla yükümlüdür. Liste için UNESCO Dünya Miras Komitesi'ne sunulacak bir mirasla ilgili dosyanın vazgeçilmez bileşenlerinden birisi de miras alanının ve tampon bölgenin sınırlarını gösterir haritalardır. Bir taraf devlet, ulusal ölçekte yasalar ve diğer yaptırım araçlarını kullanarak sınırlarını belirlediği miras alanlarının korunmasından sorumludur. Çalışmada, UNESCO Dünya Miras Listesi'nde yer alan benzer nitelikteki mimarî mirasların, tanımlanan alanları ve tampon bölgeleri incelenerek Türkiye UNESCO Geçici Listesi'ne 2000 yılında tanımlanan Sümela Manastırı kültürel mirasının alan tanımlamalarına yönelik öneriler geliştirilmiştir. Liste'de yer alan miraslarda, büyük ölçekli ve ilişki kurdukları doğal çevrelerini içeren alan tanımlaması uygulandığı tespit edilmiştir. Sümela Manastırı'nın bulunduğu Maçka İlçesi'nin de Liste'deki miraslara benzer nitelikte, Altındere Vadisi Millî Parkı, Sümela-Altındere Vadisi Doğal Sit Alanı gibi doğal mirasları ve tarih içerisinde Sümela Manastırı ile etkileşim içerisinde olan Vazelon, Panagia Keramesta ve Kuştul Manastırları gibi benzer nitelikteki kültürel mirasları barındırdığı gözlemlenmiştir. Adaylık dosyası için tanımlanacak miras alanı ve tampon bölgesinin, bahsi geçen miraslarla birlikte ele alınmasının, Liste'nin mevcut durumuna daha uygun düşeceği ve yerel getirilerinin daha fazla olacağı sonucuna varılmıştır.

Anahtar Kelimeler: Ortodoks kaya manastırları, kültürel varlık koruma, miras alanı ve tampon bölge, Bizans mimarîsi, Ayazma.

\section{Recommendations on the Delimitation of the Property Area and the Buffer Zone of Sumela Monastery Cultural Heritage}

\footnotetext{
Abstract

States parties to the UNESCO Convention on the Protection of the World Cultural and Natural Heritage are obliged to include in their UNESCO tentative list the heritage they wish to inscribe on the UNESCO World Heritage List. Maps showing the boundaries of the property area and the buffer zone are one of the indispensable components of a candidate heritage file to be submitted to the UNESCO World Heritage Committee. A state party is nationally responsible for the protection of the determined heritage sites by law and other 
sanctions. In this study, recommendations are made for defining the property area and the buffer zone of Sumela Monastery which was registered in the UNESCO Tentative List of Turkey in 2000, by examining property areas and buffer zones of similar heritages in the UNESCO World Heritage List. It is observed that a large-scale field definition was applied for the similar heritages, including the natural environment they related to. Similar to the heritages in the list, Maçka district where the Sumela Monastery is located, hosts natural heritages such as the Sümela-Altındere Valley Natural Protected Area, the Altındere Valley National Park and similar cultural heritages such as Vazelon, Panagia Keramesta and Kuştul Monasteries that were in interaction with Sumela Monastery in history. It is concluded that defining the property area and buffer zone by covering the mentioned heritages would be more suitable for the current situation of the list and more beneficial for the district.

Keywords: Orthodox rock monasteries, cultural property protection, property area and buffer zone, Byzantine architecture, holy spring. 


\section{GİRIŞ}

Bizans İmparatorluğu'nun Hristiyanlık inancını resmîleştirmesinin ardından eğitim faaliyetleri için imparatorluğun çeşitli bölgelerinde manastırlar yapılmıştır. Bu dönemde üretilen üç manastır türünden söz edilebilir. Bunlardan ilki sadece din adamlarına yönelik manastırlardır. İkincisi, günümüzde kızlar manastırı olarak da bilinen ve sadece din kadınlarına açık olan manastırlardır. Üçüncüsü ise kadın ve erkeklerin karışık eğitim gördüğü manastırlardır. Erişilmesi zor, engebeli arazilerde özellikle sarp kayalıklardaki mağaraların önlerine kurulan manastırlar, genellikle din adamları için yapılan manastır türü olmuştur. Anadolu'daki Ortodoks inancı temsilcilerinin önemli bir bölümü, Lozan Barış Anlaşmasına ek olarak 1923 yılında yapılan Türkiye Yunanistan Nüfus Mübadelesi sonucunda Türkiye'den ayrılmış ve bu tür yapılar atıl durumda kalmıştır. Bu durum, manastırlarda çeşitli mimarî koruma sorunlarına yol açmış ve birçoğu yok olmaya yüz tutmuştur. Maçka'da bulunan ve sanat tarihi bakımından türünün önemli örneklerini oluşturan kutsal mağara ve ayazma manastırlarının korunması yönünde UNESCO Dünya Miras Listesi (DML; Kalıcı Liste) önemli bir fırsattır. Ancak bir miras Kalıcı Liste'ye alınmadan önce bir önkoşul olarak UNESCO Dünya Miras Merkezi'ne bildirilen Dünya Kültürel ve Doğal Mirasının Korunmasına Dair Sözleşme'ye taraf devletlerin UNESCO geçici listelerine kayıt ettirilmelidir (UNESCO Dünya Miras Merkezi, 2019, s. 23). Taraf devlet geçici listesine alınan bir mirasın adaylık dosyası için UNESCO Dünya Miras Komitesi'nin belirlemiş olduğu bazı şartların yerine getirilmesi gerekir. Bu koşullardan birisi, tanımlanmış miras alanı ve tampon bölgesi sınırlarını belirten haritalardır (UNESCO Dünya Miras Merkezi, 2019, s. 30 ve 35). Haritalar, taraf devletin korumayı garanti ettiği alanların sınıların belirgin bir şekilde yansıtır ve böylece, alandaki koruma faaliyetleri, UNESCO'nun ilgili birimleri tarafından denetlenebilir. Tanımlı miras alanı, taraf devletin tanımlamış olduğu mirasın fiziksel sınırları ile kısıtlı kalmak zorunda değildir. İçerisinde katı koruma kuralları uygulanan bir alanı tanımlar. Tampon bölge ise miras alanını çevreleyen imarsal bir takım yasal korumaları içerir. İmarsal faaliyetler, mirasa saygı duyacak şekilde kısıtlansa da belirli bir düzeye kadar izin verilir. Bu iki alanda denetimi ve uygulamaları gerçekleştirmek adına alan yönetimi oluşturulur. Alan yönetiminin alanı ne şekilde yöneteceğini belirlemek ve değişikliklerden etkilenmesinin önüne geçmek için yönetim planı hazırlanır. Yönetim planı, UNESCO Dünya Miras Komitesi tarafından denetime tabidir. UNESCO Dünya Miras Merkezi'nin ilgili danışsal organları tarafından periyodik olarak denetlenir ve durumları hakkında Komite'ye rapor sunulur. Komite bu raporlar doğrultusunda, mirasın koruma durumunu yeterli bulmazsa yönetim planı üzerinde değişiklik talep edebilir. Komitenin ilgili uyarıları, tavsiyeleri ve gerekirse yaptırımları doğrultusunda taraf devlet, mirası koruma konusunda yeterliliği yakalayabilmek adına tedbirlerini almakla yükümlüdür. Yapılaşmış alan arttıkça, alanlardaki kontrol ve denetim de zorlaşır. Bu sebeplerle Sözleşme'ye taraf bir devlet, dünya miras alanlarını ve tampon bölgelerini tanımlarken kontrol edebileceği alan büyüklüklerini tercih eder. Miras koruma kontrol mekanizmaları güçlü olan taraf devletler daha geniş miras alanlarını daha kolay tanımlayabilmektedir.

Çalışmada, Türkiye UNESCO Geçici Listesi'ne 25 Şubat 2000 tarihinde tanımlanan Sümela Manastırı kültürel mirasına yönelik adaylık dosyasında yer alması gereken yönetim alanı ile ilgili Kalıcı Liste'deki benzer örnekler incelenerek bir tartışma yürütülmüştür. DML'deki benzer erken dönem Bizans kaya manastırları örneklerinin doğal çevreleri ile birlikte, geniş bir alan içerisinde birbirleri ile ilişkili manastır grupları olarak tanımlandıkları, 
inzivaya çekilmek için dönemin yerleşim birimlerinden belirli bir uzaklıkta fakat erişilebilir bir mesafede konumlanan manastırların bugün şehirleşmeden korundukları ancak kültürel turistler için erişilebilir oldukları görülmüştür. Bu bağlamda Sümela Manastırı yönetim alanı için mevcut potansiyel miraslar incelenmiştir. Sümela Manastırı ile yakın dönemlerde kurulan manastırlar, mevcut halde koruma altına alınan doğal miraslar ve Sümela Manastırı ile ilişkili, yakın çevredeki manevî taşınmaz miraslar incelenerek yönetim alanı için kapsaması gerekli görülen varlıklar önerilmiştir. Tüm bu ilişkili varlıkların yönetimsel olarak tek bir ilçede toplanması, Osmanlı Devleti döneminde Maçka'nın inançsal gerekçelerle yönetimsel olarak tanımlanmasına bağlanabilir. Yönetim alanı için bir avantaj sağlayan bu tek siyasî yönetim bölgesinde bulunma durumu önerilen alanın genişliğinin getirmiş olduğu kontrol zorluklarını bir nebze de olsa kolaylaştırmaktadır. Ancak Liste'de yer alan benzer örneklerde de aynı zorlukları görmek mümkündür. Ayrıca Sümela Manastırı ile ilişkili Ortodoks dinî mirasının korunmuşluk durumunda da eksikler tespit edilmiştir. Bu durum Sümela Manastırı kültürel mirasının adaylık sürecini uzatacaktır fakat getirisi çok daha fazla olacaktır. Üstelik yerel yönetimin konu ile ilgili duyarlılığının yüksek olması ve hâlihazırda söz konusu miraslar için onarım ve yenileme çalışmalarının başlatılmış olması, öneriler doğrultusunda bir avantaj sağlamaktadır.

\section{SÜMELA (MERYEM ANA) MANASTIRI KÜLTÜREL MİRASI}

Maçka İlçesi Altındere Köyü'nde, Altındere Vadisi Millî Parkı içerisinde, Karadağ'ın vadiye bakan doğu eteklerinde, dik bir kayalıkta bulunmaktadır. Sümela Manastırı'nın Atina'dan gelen Barnabas ve Sophronios isimli iki rahip tarafından (Miller, 1926, s. 61) Bizans İmparatoru I. Theodosius zamanında (379-395) kurulduğu düşünülmektedir (Kılıçaslan, 1996, s. 185). Ancak Alikılıç (2001, s. 306), İmparator I. Konstantinos'un (324-337) Sümela Manastırı'na pek çok hediyeler gönderdiğinden bahseder. Bu da manastırın düşünülenden çok daha eski olduğunu göstermektedir. Iustinianus (527-565), manastırın genişletilmesini istemiş ve değerli yazmalar ve eşyalar hediye etmiştir (Alikılıç, 2001, s. 306; Tüfek, 1978, s. 80). Yağmalanarak yakıldığı 7. yüzyıldan sonra Komnenos Hanedanlığı döneminde, 13. yüzyılda manastıra verilen önem artmıştır. Sadece manastırın asıl kurucusu olarak da görülen III. Aleksios (1349-1390) döneminde değil, onun babası, dedesi ve büyük dedesi döneminde de Sümela Manastırı'na özen gösterilmiş, manastırda çeşitli onarım ve yenileme çalışmaları yürütülmüştür (Trabzon Turizm Müdürlüğü, 1993, s. 17-8; Eyice, 1996, s. 83). Hatta III Aleksios'un büyük dedesi II. Ioannes (1280-1285) döneminde manastırın bir inanç merkezi durumunda bulunduğu da bilinmektedir (Alikılıç, 2001, s. 306). Manastırın dış kapısı üzerinde kalmayı 1650 yılına kadar başaran 1360 yılına tarihli beş mısralık bir manzum kitabede III Aleksios, bu manastırın kurucusu, doğunun ve batının hâkimi olan imparator olarak gösterilmiştir (Eyice, 1966, s. 249). İmparator, manastırda Evgenios Kilisesi'ni yeniden yaptırmış, Panaghia Theoskepastos kadınlar manastırında süsleme ve yapı genişletme çalışmaları yürütmüş ve Sümela Manastırı'nı inşa ettirmiştir (Eyice, 1966, s. 249; dipnot 14). Ölümünden sonra Komnenos Hanedanlığı'nın başına geçen III. Manuel (1390-1417) de Sümela Manastırı'na önem vermiş, saray hazinesinde bulunan bir stauroteği manastıra hediye etmiştir (Eyice, 1966, s. 250). Manastır, III. Aleksios, III Manuel ve Andronikos tarafından onarılmıştır (Fallmerayer, 2002, s. 129). III. Aleksios döneminde fresklerle süslenen kilise ve şapel, III. Manuel döneminde yeniden fresklerle süslenmiştir (Durmuş, 2016, s. 105; Şen, 1998, ss. 165-70). Böylece 14. yüzyıldan kalma iki katmanlı bir duvar süslemesi oluşmuştur. Osmanlı Devleti'nin yönetimi altına girdiğinde ise manastıra 
çeşitli ayrıcalıklar tanınmış ve padişahlar tarafından çeşitli hediyeler yollanmıştır. Manastırın haklarının tanındığına dair Fatih Sultan Mehmed, II. Beyazid, II. Selim, III. Selim, IV. Murad, İbrahim, IV. Mehmed, Kanunî Sultan Süleyman, II. Mustafa ve III. Ahmed'e ait fermanların, bir dönem manastırda arşivlendiği bilinmektedir (Eyice, 1996, s. 83). Eflâk voyvodaları, 18. yüzyılda manastırla yakından ilgilenmiştir. Başpiskopos Ignatios tarafından manastırda, 1749 yılında onarım çalışmaları yürütülmüş ve yeni freskler yaptırılmıştır (Eyice, 1966, s. 251). Voyvodalardan Gikas, Stefan ve İpsilantis, manastıra yardımda bulunmuşlardır (Eyice, 1996, s. 83). Sümela Manastırı, en parlak dönemini 19. yüzyılda yaşamış, önemli ölçüde imar edilmiş ve süslemelerle dekore edilmiştir. Manastır, 1923 yılında Mübadele imzalandıktan sonra boşaltılınca el yazması eserler ve kutsal emanetler faklı bölgelere dağılmıştır. Bir bölümünün Ankara'da, bir bölümünün İstanbul Arkeoloji Müzesi'nde, bir bölümünün Atina Bizans Müzesi'nde, bir bölümünün Atina Benaki Müzesi'nde, tam olarak nerede olduğu bilinmese de bir bölümünün Yunanistan'da olduğu, bir bölümünün piyasada satıldığı ve bir bölümünün de kayıp olduğu bilinmektedir (Eyice, 1966, s. 258). Veria'da 1952 yılında "Sümela Manastırı" adlı yeni bir manastır yaptırılması üzerine, Benaki Müzesi'nde bulunan kutsal emanetler buraya taşınmıştır (T.C. Kültür ve Turizm Bakanlığı, 2020a).

Manastırda, ana kilise, şapeller, mutfak, depolama alanları, misafirhane, öğrenci odaları, rahip odaları, kütüphane ve kutsal ayazma yer almaktadır. Kompleksin giriş tarafından yapı grubuna su taşıyan ve Karadağ'a yaslı şekilde oluşturulan bir sukemeri bulunur. Manastırın giriş bölümüne, bu sukemerine yaslı halde bulunan taş malzemeden dar, uzun ve dik bir merdivenle ulaşılmaktadır. Birçok defa yağmalanan manastırın güvenliğini sağlamak amacı ile manastırın girişi, kesme taşlarla örülerek daraltılmış ve muhafız hücreleri eklenmiştir. Giriş, yükseltilerek ahşap bir merdivenden tırmanmayı gerektirecek şekilde yenilendikten sonra ahşap merdiven, 1850'li yıllara kadar geceleri kaldırılarak güvenlik sağlanmıştır (Köse, 2012, s. 12). Kapıdan geçildikten sonra, üzeri beşik tonoz ile örtülü yaklaşık üç metrelik giriş koridoruna erişilmektedir. Koridor, giriş avlusuna erişimi sağlamaktadır. Üst koddaki giriş avlusundan uzun ve dik bir merdivenle ana avluya inilir. Merdivenden inilirken sol tarafta, ilki giriş avlusu olmak üzere beş dik terastan oluşan bir teraslama bulunur. Merdivenin sağında ise muhafız odaları ile başlayan ve merdiven boyunca aşağıya kadar devam eden, diğer tarafında vadinin uçurumuna bakan çeşitli mahaller yer almaktadır. Karadağ'ın iç tarafına doğru, kayanın oyulması ile elde edilen bir alan içerisinde (merdivenlerden inildiğinde sol tarafta kalmaktadır) ve serbest düzende manastırlar yer almaktadır. Bu bölge, manastırın en eski bölgesidir. Burada eski bir kilise ve kilisenin güney cephesine bitişik halde bir şapel bulunmaktadır. Kilise, kutsal mağara olarak bilinen ve muhtemelen manastırın ilk bölümü olan kısmın içinin oyularak düzeltilmesi ve girişinin duvar örülerek kapatılması ile oluşturulmuştur. Kilisenin (şapel dâhil) iç ve dış duvarları fresklerle süslenmiştir. Doğu cephesine bitişik halde bir çile odası yer almaktadır. Kilise ve çile odasının güneydoğusunda avluyu sınırlayan yemekhane bulunmaktadır. Yemekhane ile şapel arasında bir de çan kulesi vardır. Yemekhanenin arka tarafında, Karadağ'ın içlerine doğru (yemekhanenin kuzeydoğusunda) inziva odaları yapılmıştır. Avlunun güney bölümünü ise manastırın bulunduğu mağaranın ağzını kapatırcasına üçdört kat yükselen bir dizi yapı grubu oluşturur. Giriş kapısı ile avlu bağlantısının güney tarafında muhafız odaları ve kütüphane bulunmaktadır. Kütüphanenin doğusunda ona bitişik halde ve vadiye doğru taşma yapan yatakhaneler bloğu yer almaktadır. Avlunun Altındere Vadisi'ne bakan tarafında 1860'lı yıllarda yapımı tamamlanan misafir odaları ve 
kütüphane yer almaktadır. Avluya yayılı halde daha birçok şapel bulunmaktadır. Eski tarihlerde avluya doğru çıkma yapan, ahşap malzemeden üretilmiş balkonların da olduğu bilinmektedir (Rice, 1930, fotoğraf 26). Ancak atıl durumda kalan manastırda 1930 yılında çıkan bir yangın sonucunda, manastırın tüm ahşap yapı elemanları yok olmuştur (Eyice, 1996, s. 86). Avludan geçilen dar bir koridor ile heybetli, asıl manastır yapısına ulaşılmaktadır. Vadiden algılanan geniş cephenin son bölümü, bu yapıya aittir. Üç ana katın dışında alt katlarda mahzenler ve üstte bir çekme kat bulunmaktadır. Çekme katta çatı, alt kat hizasına kadar öne taşırılmış saçaklar ve bu saçakları taşıyan kemerlerden oluşturularak seyir terasları elde edilmiştir. Bu bölümün 1860 yılında yapıldığı sanılmaktadır (Eyice, 1966, s. 260). Yapılan güncel restorasyon çalışması kapsamında, 2018 yılında varlığı unutulan gizli çilehaneler de açı̆̆a çıkarılmıştır (Başar \& Bayram, 2018).

Sümela Manastırı, T.C. Kültür Bakanlığı tarafından 1972 yılında sit alanı, 1981 yılında doğal sit alanı ilân edilmiştir. Altındere Vadisi'ne, 1987 yılında millî park statüsü verilerek koruma altına alınmıştır. Trabzon Kültür ve Tabiat Varlıklarını Koruma Kurulu tarafından 1997 yılında I. derece doğal ve arkeolojik sit alanı ilân edilmiştir (Doğanay, 2003, s. 53; Zaman, 2005, s. 13). T.C. Kültür ve Turizm Bakanlığı tarafından 25 Şubat 2000 tarihinde Türkiye UNESCO Geçici Listesi'ne, dünya miras alanı kriterlerinden kriter 1 ve kriter 3 gerekçe gösterilerek 1397 referans numarası ile yazdırılmıştır (UNESCO, 2020). Terk edildikten sonra ilk defa manastırda ayin yapılması için 15 Ağustos 2010 tarihinde, T.C. Kültür ve Turizm Bakanlığı tarafından verilen özel izin ile Fener Rum Patriği Dimitri Bartholomeos yönetiminde Meryem Ana'nın Göğe Yükseliş Günü için ayin düzenlenmiştir (BBC News, 2010). Bu tarihten sonra taş düşme riskine ve restorasyon çalışmalarına yönelik 22 Eylül 2015 tarihinde ziyarete kapatıldığı tarihe kadar altı yıl boyunca her yıl aynı tarihte ayin düzenlenmiştir (İHA, 2018).

\section{UNESCO Dünya Miras Listesi'nde Benzer Miraslar ve Yönetim Alanları}

UNESCO Dünya Miras Listesi'nde yer alan, sırtını sarp bir kayalığa yaslamış, bir bölümünün kayalık arka planın oyularak oluşturulduğu, erken dönem Hıristiyanlığı için önemli yerleşim birimlerinden oluşan, normal yerleşim birimlerinden uzakta, doğa ile iç içe ve genellikle bir vadiye bakan manastırların tanımladığı miraslar incelendiğinde üç örnek göze çarpmaktadır (Tablo 1). Bu örneklerden ikisi Yunanistan Cumhuriyeti Devleti, diğeri Lübnan Cumhuriyeti Devleti sınırları içerisinde yer almaktadır (Şekil 1). Sümela Manastırı kültürel mirası ise bu mirasların dağıldığı coğrafyada, iki ülke arasındaki dağılımda bir geçiş sağlar nitelikte konumlanmıştır. Sümela Manastırı da dâhil olmak üzere tüm örnekler, ormanlık alanlar içerisinde ve doğal çevre ile güçlü ilişkiler kuracak şekilde kurgulanmıştır. 


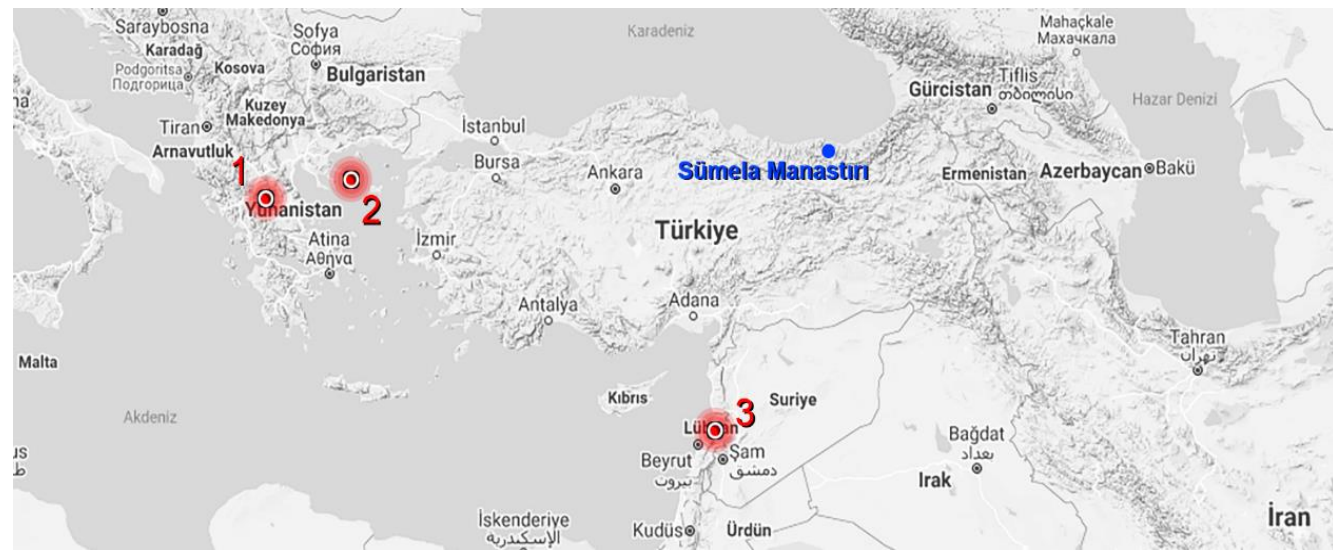

Şekil 1. UNESCO Dünya Miras Listesi'nde Sümela Manastırı ile benzer nitelikteki miraslar (Coğrafî bilgi sistemi (2021) ve UNESCO (2020) kaynaklarından veriler işlenerek dijital ortamda hazırlanmıştır): 1. Meteora, 2. Athos Dağı, 3. Kadişa Vadisi ve Tanrı'nın Sedirleri Ormanı.

Meteora: Yunanistan'ın coğrafî olarak merkezinde yer almaktadır. Tırhala (Trikala)'nın 21 km kuzey batısında bulunan Kalambaka (Kalabaka)'nın kuzey ucundaki kayalık bölge içerisinde yayılı bir halde yer alan manastır komplekslerini içermektedir. Miras alanı olarak 271,88 ha koruma alanı ve 1.884,14 ha tampon bölge alanı tanımlanmıştır. Sözleşmeye taraf devlet olarak Yunanistan Cumhuriyeti Devleti tarafından 1988 yılında, kriter 1, 2, 4, 5 ve 7'yi karşıladığ gerekçelendirilerek 455 referans numarası ile DML'ye yazdırılmıştır (UNESCO, 2020). Keşişleri barındıran bölgede ilk yerleşimin 11. yüzyılda gerçekleştiği düşünülmektedir. Bölgenin canlı olduğu 14.-15. yüzyıllarda 24 adet manastır kompleksi inşa edilmiştir. Günümüzde manastırlardan ayakta kalmayı başaran 7 adedi koruma altına alınmıştır. Bu manastırlardan 4 adedi, hala aktif olarak dinî faaliyetlerin gerçekleştirildiği, rahip ya da rahibeler tarafından yaşatılan yapılardır. Önemli fresklerin yer aldığı manastırlar, Bizans Dönemi sonrası bölgedeki resim sanatının gelişimini göstermesi bakımından sanat tarihi içerisinde önemli bir yer tutmaktadır.

Athos Dağı: Yunanistan Cumhuriyeti'ndeki Halkidiki Yarımadası'nın üç kolundan doğudaki kolunun tamamını kapsamaktadır. Keşişsel özerk statüdeki bölgeye bin yıldır kadın ve çocukların girmesi yasaktır. Günlük 100 Ortodoks ve 10 Ortodoks olmayan yetişkin erkek ziyaretçi bölgeye kabul edilmektedir. Manevî olarak İstanbul Ortodoks Rum Patrikhanesi'ne bağlıdır ${ }^{1}$. Hristiyanlığın ilk dönemlerinde keşişlerin inzivaya çekilmek için yerleştiği bölge, zamanla gelişerek bir inanç merkezine dönüşmüştür. Yüksek kayalıkların tepelerine yapıldıkları için ilk yıllarında manastırlara ulaşım iplerden örülen fileler aracılığı ile sağlanırken sonraları merdivenlerle ulaşılmaya başlanmıştır. Bölge, 1054 yılında Ortodoks manevî merkezi haline gelmiştir. Kutsal kabul edilen 33.042,3 ha alana yayılan yarımada kolunun (Aynoroz, Aynaroz) tamamı dünya miras alanı olarak tanımlanmıştır. Alanın geneline yayılan 20 adet önemli manastır bulunmaktadır. Aynoroz toprakları bu manastırlar arasında paylaşılmış durumdadır ve her manastır kendi alanının yönetiminden sorumludur. Keşişsel özerk devletin karar mekanizmasını ise her manastırın birer temsilcisinin yer aldığı Mukaddes Meclis üstlenmiştir (Eyice, 1991, C. 4, s. 268). Yunanistan

\footnotetext{
${ }^{1}$ Fener Rum Patrikhanesi olarak da bilinir. Dördüncü Haçlı Seferi sonucunda dağılan Bizans İmparatorluğu'nu toparlayan II. Andronikos, 1312 yılında Aynoroz manastırlarını Konstantinopolis Patrikhanesi'ne bağlamıştır. Ayrıntılı bilgi için bk. Eyice, 1991, C. 4, ss. 267-9.
} 
Cumhuriyeti Devleti tarafından 1988 yılında, kriter 1, 2, 4, 5, 6 ve 7'yi karşıladığı gerekçelendirilerek 454 referans numarası ile DML'ye yazdırılmıştır (UNESCO, 2020). Hem mimarî olarak hem de DML süreçleri olarak Meteora ile büyük benzerlikler gösterir. Bu iki miras, 2021 yılı itibariyle Yunanistan Cumhuriyeti Devleti'nin DML'ye kayıt ettirdiği karma mirasların tamamını oluşturmaktadır.

Kadişa Vadisi (Kutsal Vadi) ve Tanrı'nın Sedirleri Ormanı: Lübnan Cumhuriyeti Devleti'nin Şimal İli sınırlarında, Becharre ve Zgharta İlçeleri arasında, el-Makmal Dağı eteklerinde bulunan bir boğaz şeklindedir. Lübnan Cumhuriyeti Devleti tarafından 1998 yılında, kriter 3 ve kriter 4 gerekçe gösterilerek 850 referans numarası ile DML'ye kayıt ettirilmiştir. Miras alanı olarak birbirine yakın iki lokasyonda toplam 1.720,2 ha'llk alan tanımlanmıştır. Erken Hristiyanlık döneminde önemli manastır yerleşimlerinden birisi olmuştur. Kadişa Vadisi'nde yayılı halde dördü ana manastır (Qannubin Manastırı, Quzhayya St. Anthony Manastırı, Haqqa Meryem Ana Manastırı, Mar Lichaa Manastırı) olmak üzere toplam dokuz manastır bulunmaktadır (UNESCO, 2020). Manastır çevrelerinde tarımsal teraslamalar yapılmışır. Bölgedeki Tanrı'nın Sedir Ormanları, Antik ormanların son kalan parçasını temsil etmektedir ve Antik Dönem'in en önemli inşaat malzemelerinden olan Lübnan Sediri (Cedrus Libani) ağacının hala görüldüğü ender yerlerden birisidir. Miras, diğer iki kaya manastır dünya mirası gibi karma miras olarak DML'ye sunulmuş ancak tanımlanan doğal miras alanının yetersiz bulunması sebebi ile ilgili danışsal organın da tavsiyesi üzerine UNESCO Dünya Miras Komitesi tarafından doğal miras özellikleri kabul edilmemiştir (UNESCO, 2020). Bölgede devam eden yasadışı inşaat faaliyetleri yüzünden miras, Tehlike Altındaki Dünya Mirasları Listesi'ne alınma tehlikesi ile karşı karşıyadır.

Tablo 1. DML'de Sümela Manastırı ile mimarî benzerlik gösteren miraslar

\begin{tabular}{llllll}
\hline Miras & $\begin{array}{l}\text { Kayıt } \\
\text { Yılı }\end{array}$ & $\begin{array}{l}\text { DMA } \\
\text { Kriterleri }\end{array}$ & $\begin{array}{l}\text { Miras } \\
\text { (ha) }\end{array}$ & $\begin{array}{l}\text { Alanı } \\
\text { Alanı (ha) }\end{array}$ \\
\hline Meteora & 1988 & $1,2,4,5,7$ & 271,9 & 1884,1 \\
Athos Dağı & 1988 & $1,2,4,5,6,7$ & 33042,3 & - \\
$\begin{array}{l}\text { Kadişa Vadisi ve } \\
\text { Tanrı'nın Sedirleri } \\
\text { Ormanı }\end{array}$ & 1998 & 3,4 & 1720,2 & - \\
\hline
\end{tabular}

Kaynak: UNESCO (2020)'den veriler derlenerek.

\section{Maçka İlçesi'nde Diğer Benzer ya da İlişkili Manastır Mirası}

Tarihi, Antik Döneme kadar dayanan Maçka, tarihî İpek Yolu üzerinde yer almıştır. Bu sebeple ticarî, ekonomik, sanatsal, sosyal ve imarsal olarak gelişmiştir. Ancak en çok gelişimi inanç konusunda göstermiştir. Bizans döneminden itibaren önemli inanç merkezlerinden birisine dönüşmüştür. Erken dönemlerde bölgede kurulan üç büyük manastırın varlığından söz etmek mümkündür. Osmanlı Devleti'nin inançlara saygı duyan iç politikası gereği bölgeye hâkim olmasından sonra da manastırlar faaliyetlerini sürdürmüş 
ve gelişerek büyümüşlerdir. Bir müddet sonra bölge, Ortodoks inancı için oldukça önemli bir kutsal alana dönüşmüştür.

Bu konuda bölgenin Ortodoks inancındaki önemini anlatan Günday'ın hatıralarına ${ }^{2}$ bakmakta yarar vardır. Günday, Meşrutiyetin ilânından sonra Maçka'da yaşanan Müslümanlıktan dönme olaylarına yönelik yapılan tahkikatların anlatıldığı bölümde tespitlerini şöyle aktarmaktadır;

“...Buna mukabil Ortodokslarm her tarafta, her köyde, her yerde papazlarl, kiliseleri ve manastırları bulunduğu tespit edildi. Maçka nahiyesi Ortodoksluk âleminde Kudüs ve Aynoroz'dan ${ }^{3}$ sonra üçüncü mukaddes bir yerdi. Bunun kutsiyeti havarilerden birinin oraya gitmiş olmasıdır. Maçka müstakil bir metropolitlik idi... Maçka Ortodoks kiliseleri çok zengindi. Yüzlerce papaz ve târik-i dünyalar o manastırlarda yaşıyorlardı..." (Günday, 1960, s. 23).

Günday (1960) ayrıca, Islahat Fermanı (1856) ile Maçka'da yeniden yapımı ya da onarımı gerçekleştirilen kiliseleri aktarmış ve Maçka'nın o dönem, Ortodoksluk için ne kadar önemli bir inanç merkezi olduğunu göstermiştir. Buna göre Kapıköy (başvurusu Islahat Fermanından önce), Larhan, Kutala (Yemişli), Konaka, Zanha (iki adet kilise), Bondila (Pondila) ve Hortokob-1 Zir Köylerindeki kiliselerde bakım ve onarıma yönelik Osmanlı Devleti'ne başvurulmuştur (Ayar, 2017, ss. 5-12).

Tarih içerisinde Sümela Manastırı ile sürekli ilişkide olan iki köklü manastır daha bulunmaktadır; Vazelon Manastırı ve Kuştul Manastırı (Şekil 2). Manastırlarda bulunan kitaplıklar, Trabzon'un bilinen ilk kütüphaneleri olarak kente kültürel katkıda bulunmuştur (Alikılıç, 2001, ss. 306-8). Manastırlarda bulunan freskler sanat tarihi açısından önemlidir. Kendilerine tanınan ayrıcalıklarla 14. yüzyıldan itibaren sürekli olarak manastırların sahip oldukları toprak miktarı artmıştır. Öyle ki, 1890 yılına gelindiğinde Kuştul Manastırı 11, Sümela Manastırı 15, Vazelon Manastırı 20 adet köyün sahibi olmuştur (Bryer \& Winfield, 1985, C. 1, s. 252). Ancak her üç manastır da, 1923 yılında Lozan Barış Anlaşması'na ek olarak yapılan Türkiye Yunanistan Nüfus Mübadelesi sonucunda terk edilerek atıl duruma düşmüştür. Alanda daha küçük boyutlarda ayazması bulunan manastırlar olması muhtemeldir. Panagia Keramesta Manastırı bunların bilinenlerindendir. Manastırların yakın çevrelerine tamamlayıcı nitelikte bazı yapılar da üretilmiştir. Bu bağlamda, çalışmada Sümela Manastırı'nın yakınlarındaki St. Barbara Şapeli ve Vazelon Manastırı'na yakın konumdaki Panagia Keramesta Manastırı da bölgedeki kültürel bütünlük kapsamında incelenmiştir.

\footnotetext{
${ }^{2}$ Ahmet Faik Hurşit Günday, Sivas Valiliği ve TBMM 2. Dönem Ordu Milletvekilliği görevlerinde bulunmuştur. Görev gereği Trabzon'a 1908 yılında gitmiş ve yaşadıklarını Hayat ve Hatıralarım adlı eserinde aktarmıştır. Eserde, Cilt: 1 ibaresi olsa da eserin başka cildi çıkarılmamıştır. ${ }^{3}$ DML'de Athos Dağı olarak kayıtlı olan uzun yarımada kolu. Resmî adı Aynoroz Özerk Keşişsel Devleti'dir.
} 


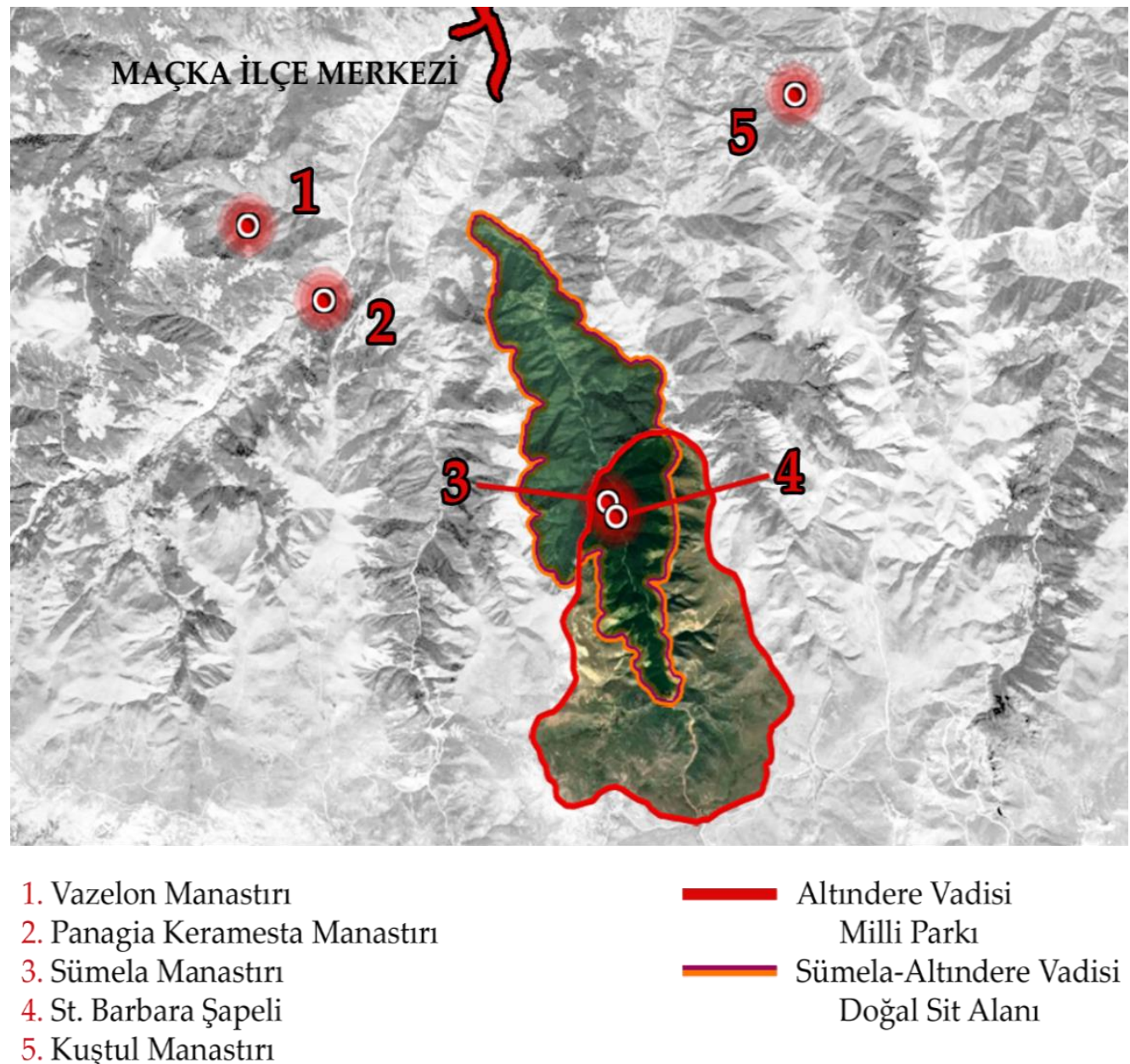

Şekil 2. Maçka İlçesi'nin Sümela Manastırı kültürel mirası ile benzer nitelikteki kültürel mirasların ve ilişkili doğal mirasların coğrafî dağılımı (Coğrafî bilgi sistemi (2021) kaynağından coğrafî veriler işlenerek dijital ortamda hazırlanmıştır)

Vazelon (Yahya) Manastırı: Köprüyanı ve Kiremitli Mahallelerinin yaklaşı $2 \mathrm{~km}$ batısında, Zabulon Dağı'nın doğu yönünde, vadiye bakan bir kayalığa yaslı halde bulunmaktadır. Sümela Manastırı́nın Vazelon Manastırı'na mum vergisi ödediği, dolayısıyla Sümela Manastırı'ndan daha eski olduğu bilinmektedir. Yapılış tarihine dair tam bir tarihlendirme yapılamasa da MS 270-317 yılları arasında bir tarihte yapıldığı düşünülmektedir ${ }^{4}$. Iustinianus tarafından 565 yılında onarılan manastıra 644 ve 702 yıllarında eklemeler yapılmış ve onarım çalışmaları yürütülmüştür (Kılıçaslan, 1996, s. 185). Yapının temellerine inildikçe 4. yüzyıl izlerine rastlamak mümkündür. Ayakta kalan yapı bölümü 14. ve 19. yüzyıla aittir. Manastır yapı topluluğu içerisinde üç Bizans bazilikası ve bir tonozlu sarnıç bulunmaktadır. Ayazmanın bulunduğu mağaranın önüne yapılan kilise, üç nefli bazilikal planlıdır. Sümela Manastırı'nda olduğu gibi 19. yüzyılın sonlarına kadar girişte, geceleri kaldırılan ahşap bir merdivenle erişim sağlanmış, bu tarihten sonra taştan merdivenler yapılmıştır (Köse \& Demciuc, 2014, s. 262). Manastır dört katlıdır ve ön tarafta dördüncü kat cephesi Sümela Manastırı'nın kuzey cephesi ile önemli ölçüde benzerlikler göstermektedir. Ayrıca cephe tarzı ve ön taraftaki balkonlar da Sümela Manastırı ile

${ }_{4}$ Yabancı kaynaklarda (Bryer, Winfield, Ballance \& Isaac, 2002, s. 298) manastırın kuruluş tarihi olarak MS 270 yılı işaret edilirken yerli kaynaklarda (Horuluoğlu, 1978, ss. 60-1; Canalioğlu, 1991, s. 22) MS 317 yılı işaret edilmektedir. 
benzerlikler göstermektedir. Her iki cephe de 20. yüzyılın ilk çeyreğinde yapılmıştır (Köse \& Demciuc, 2014, s. 262). Kilise batı duvarının tamamında Mahşer ve Hetoimasia sahnelerinin yer aldığı freskler görülmektedir (Yılmaz, 2015, s. 144). Kilisenin kuzeyinde yer alan dış duvarlarda ise Cennet, Cehennem ve Mahşer Günü tasvirli freskler bulunmaktadır. Vergilerden dolayı ekonomik durumu bozulan manastırın yönetimi, 1859 yılında Sümela Manastırı başrahibi Anthimios'a devredilmiştir (Yılmaz, 2015, s. 141). Manastırdaki son yıkımın yaşandığı 1922 yılında, manastırın son papazı olan Dionysios Amarantidis, Hz. Yahya ikonasını Yunanistan'ın Serez şehrinde bulunan Agia Triada Manastırı'na götürmüştür. İkona, daha sonra günümüzde korunduğu Rusya'nın Saint Petersburg şehrindeki Leningrad Müzesi'ne taşınmıştır (T.C. Maçka Belediyesi, 2020). Günümüzde çevresi ile birlikte manastır, Koruma Kurulu tarafından sit alanı ilan edilerek koruma altına alınmıştır. Manastırın mülkiyeti T.C. Kültür ve Turizm Bakanlığı'na, çevresinin mülkiyeti T.C. Tarım ve Orman Bakanlığı'na ait durumdadır. Avrupa Birliği fonlarından da yararlanılarak hazırlatılan proje doğrultusunda yakın dönemde restorasyon çalışmaları planlanmaktadır (DHA, 2018).

Kuştul (Hızır İlyas) (St. George Peristereota) Manastırı: Esiroğlu Beldesi, ŞimşirKuştul Köyü sınırları içerisinde yer almaktadır. Manastır, Galyan Vadisi'ne hâkim sarp bir kayalık üzerinde konumlanmıştır. Manastıra ulaşım üç adet patika yol ile sağlanabilmektedir. Bir mağara manastırıdır ve kutsal kabul edilen ayazma çevresinde yapılmıştır. Yapım tarihinin 752 yılı olduğu düşünülmektedir (Kılıçaslan, 1996, ss. 185-6; Yücel, 1988, s. 31). Manastır, 1203 yılında yağmalanmış, 1393 yılında onarılarak yeniden açılmıştır (Yücel, 1988, s. 31). Manastır, yağmalandığı 1462 yılında haydut saldırıları sonucu harap edilerek kısmen yıkılmıştır. Kısa bir süre sonra, 1483 yılında, büyük bir yangın geçiren manastırın birçok eşyası yanarak yok olmuştur. Yangından sonra, 1501 yılında İstanbul Rum Ortodoks Patrikhanesi (Ecumenical Patriarchate of Constantinople) yönetimine girmiştir (cagrisad, 2012). Manastır, 1904 yılında çıkan başka bir yangın sonucu önemli derecede hasar görmüş (Bryer \& Winfield, 1985, C. 1, s. 272), Sultan Abdülhamit döneminde onarılmıştır (Nişanyan \& Nişanyan, 2002, s. 148; Yücel, 1988, s. 31). Manastırın iç avlusunun sağında ve solunda iki-üç katlı manastır odaları bulunmaktadır. Bu odalardan kuzeyde bulunanların misafir odaları, güneyde yer alanların keşiş odaları olduğu sanılmaktadır (Yücel, 1988, s. 31). Batı cephesinden bulunan bir merdivenle manastırın geniş hollerine erişilmektedir (Yücel, 1988, s. 31). Tarihî fotoğraflarda görülen haç planlı kilise, günümüze ulaşamamıştır. Mübadele sonucu terk edildikten sonra, Selanik'te (Yunanistan) 23 Nisan 1965 tarihinde Saint George Peristereota adlı bir dernek kurulmuştur (Orthodoxian News Agency, 2019). Derneğin çabalarıyla Yunanistan'ın kuzeyinde, Selanik'in $76 \mathrm{~km}$ kadar batısında bulunan Rodochi yakınlarındaki Vermio Dağı eteklerinde, yaklaşık 200 dönümlük bir alan üzerine St. George Peristereota Manastırı yeniden inşa edilmiş ve açılışı 16 Haziran 1978 tarihinde gerçekleştirilmiştir. Yeni manastırda, Maçka'da bulunan özgün manastırdan taşınan iki mermer sütun, beş azizin kalıntıları ve hieromonk ${ }^{5}$ kutsal kemikleri saklanmaktadır (İEllada, 2019). Özgün manastır kalıntıları, T.C. Maçka Belediye Başkanlığı'nın müracaatı sonucunda T.C. Kültür ve Turizm Bakanlığı Trabzon Kültür Varlıklarını Koruma Bölge Kurulu Müdürlüğü tarafından anıt eser olarak tescillenmiştir.

St. Barbara Şapeli: Sümela Manastırı'na çıkmadan önce vadi tabanında halk arasında Aya Varvara olarak bilinen St. Barbara Şapeli bulunmaktadır. Şapel, ayakta kalan koruma

${ }^{5}$ Ortodoksluk ve Doğu Katolikliği inançlarında, rahip-keşiş unvanı taşıyan din adamı.

SEFAD, 2021; (45): 295-312 
duvarları, hücre oda kalıntıları ve kiliseden oluşmaktadır. Şapele ulaşılan güney koruma duvarındaki giriş kapısı kemersizdir ve lentosu ahşap malzemedendir. Giriş, güneybatıkuzeydoğu doğrultusunda uzanan taş döşeli dar bir sokağa açılır. Sokağın kuzeybatısını, sarp bir kayalık sınırlamaktadır. Güneydoğu yönünde ise günümüzde sadece temelleri görülen sıralı yedi adet hücre bulunmaktadır. Orta bölümde yer alan hücrelerin ocak kısımları günümüzde algılanabilmektedir. Hücreler, sokağın güneydoğusunda bulunan ve vadiye bakan uçurumla sınırlıdır. Günümüzde hücreler olmadığı için hücrelerin manzarası sokaktan algılanmaktadır. Sokağa giriş kapısı ile hücreler arasında, hücrelerden daha büyük ve hücrelerden yedi basamak daha yüksek bir konumda, koruma duvarına ve hücrelere bitişik halde bir mahal daha bulunmaktadır. Muhtemelen kullanıldığı yıllarda girişin güvenliğini sağlamak için kullanılmıştır. Sokağın kuzeydoğu ucunda, sol tarafta kilise bulunur. Sokaktan on altı basamaklı bir merdiven ile kiliseye çıkılır. Merdivenin onuncu basamağından toprak bir platforma çıkılır. Bu platform sokağın kuzeydoğu ucunu tanımlayan, sonu uçurumla sınırlı bir seyir terasıdır. Kilise, yığma yapım tekniği ile taştan yapılmıştır. Kapı ve pencere söveleri kesme taştan ve kemerli olarak yapılmıştır. Giriş kapısı, yaklaşık batı-doğu yönünde uzanan dikdörtgen bazilikal planlı şapelin güney cephesinde bulunur. Kapının sağında ve solunda, yüksekte iki adet oldukça dar pencere açıklığı yer alır. Düz duvarlı batı cephesinde ve apsisin bulunduğu doğu cephesinde, yüksekte ve oldukça dar birer pencere açılığı daha bulunmaktadır. Kuzey cephesinde de iki adet benzer pencere açılığı mevcuttur. Kilisenin üst örtüsü beşik tonozdan oluşturulmuştur. Tonoz, içeriden üç adet taştan kemer ile desteklenmiştir. Tonozun üstü kırma çatı ile kapatılmıştır. Kilise içerisindeki yığma taş duvarlar sıvanarak beyaz boya ile boyanmıştır. Manastır terk edildiğinde kutsal emanetler, rahipler tarafından bu şapele gömülmüş ve 1931 yılında özel bir izinle emanetler, şapelden alınarak yurt dışına götürülmüştür (Fallmerayer, 2002, s. 118).

Panagia Keramesta (Kızlar) Manastırı: Vazelon Manastırı'nın yaklaşık olarak $3 \mathrm{~km}$ güneydoğusunda, Kiremitli Köyü'nün yakınlarında, Hamsiköy Deresi'ne bakan tarafta yer almaktadır. Diğer örnekler gibi kutsal kabul edilen bir mağaranın önünde yapılmıştır. Manastırın isminin nereden geldiğine ya da ilk olarak kaç yılında kurulduğuna dair bir bilgi bulunmamaktadır ancak birkaç duvarı ayakta kalan ve daha yeni olduğu anlaşılan yapı, 1858 yılında yapılmıştır (T.C. Kültür ve Turizm Bakanlığı, 2020b). Manastırın ise günümüzde sadece batı ve kuzey duvarı ayakta kalabilmiştir.

\section{Maçka İlçesi'nin Doğal Mirası, Altındere Vadisi Millî Parkı ve Sümela-Altındere Vadisi Doğal Sit Alanı}

Manastırın içerisinde yer aldığı Altındere Vadisi Millî Parkı, 2873 Sayılı Milli Parklar Kanunu kapsamında, 9 Eylül 1987 tarihinde (Doğanay, 2003, s. 47), 87/12097 sayılı Bakanlar Kurulu kararı ile (Gümüş \& Eryılmaz, 2015, s. 4), 4468 hektara yayılan bir alan tanımlanarak millî park ilan edilmiştir (T.C. Tarım ve Orman Bakanlığı, 2020a). Millî parkın bulunduğu bölge bu tarihe kadar Meryemana Araştırma Ormanı olarak tanımlanmıştır (Aksu, 2015, s. 271; Sakıc1, 2005, s. 436). Günümüzde park içerisinde 909,5 hektar ormanlık alan, 3812 hektar mera ve 78,5 hektar iskân alanı tanımlanmıştır. Millî parkta yer alan ve tapusu T.C. Kültür ve Turizm Bakanlığı Vakıflar Genel Müdürlüğü'ne ait olan Sümela Manastırı için ise 2788,37 metrekarelik bir alan tanımlaması yapılmıştır (T.C. Tarım ve Orman Bakanlığı, 2020b). Millî parkın güneyinde, vadinin tabanındaki Meryemana Deresi'nin kaynağını oluşturan Çakır Krater Gölü bulunmaktadır. Bölgenin hâkim litolojik yapısı Üst Kretase yaşlı andezit, bazalt ve traki-andezit gibi volkanik formasyonlardan oluşmaktadır (Kılıçaslan, 1994, s. 5). 
Millî parkın bulunduğu Doğu Karadeniz Bölgesi'nin \%34'ünü kaplayan ormanlar, Türkiye'nin toplam orman varlığının \%7'sini oluşturur (Toksoy, Ayaz, Şen \& Özden, 2005, ss. 80-1). Trabzon İli, Türkiye genelinde 247 adet olan tabiat parklarından dokuzunu barındırmaktadır. Maçka İlçesi'nde bulunan Altındere Vadisi Millî Parkı ise Türkiye genelinde toplam sayısı 44 olan millî parklardan birisidir (T.C. Tarım ve Orman Bakanlığı, 2020c). Altındere Vadisi Millî Parkı, flora açısından oldukça zengindir ve Türkiye'nin üç büyük flora bölgesinden birisi olan Avrupa-Sibirya Fitocoğrafya Bölgesi'nin Kolşik Flora Bölümü'nde yer almaktadır (Altun, 1995, s. 26'dan aktarımla Anşin, 1978, ss. 38-40; Atalay, 1994, s. 112). Yörenin hâkim bitki örtüsünü Doğu Ladini oluşturmaktadır (Sakıc1, 2005, s. 437). Sahada bulunan diğer başlıca ağaç türleri arasında Doğu Karadeniz Göknarı, Kayın Gövdeli Akçaağaç, Doğu Karadeniz Akçaağacı, Çınar Yapraklı Akçaağaç, Ova Akçaağacı, Sakallı Kızılağaç, Tüylü Huş, Siğilli Huş, Adi Gürgen, Anadolu Kestanesi, Adi Fındık, Doğu Kayını, Adi Ceviz, Karayemiş, Hanımeli, Titrek Kavak, Mor Çiçekli Orman Gülü, Sarı Çiçekli Orman Gülü, Kafkas Ihlamuru ve Dağ Karaağacı bulunmaktadır (Menteş, 1992, s. 52). Bölgede, yükseltisi 2000 metrenin üzerindeki alanlarda görülen Alpin Çayırlar Kuşağı'ndaki mera bitki türleri arasında bulunan Narin Tavusotu, Çayır Timsahotu, Koyun Yumağı, Çayır Yulafı, Hasır Otu, Çayır Salkımotu, Altın Yulaf, Melez Üçgül, Çayır Üçgülü ve Ak Üçgül gibi türler de görülmektedir (Menteş, 1992, s. 54).

İçerisinde yaklaşık olarak 3 hektarlık bir alanın yaban hayatı koruma alanı için ayrıldığı (Sakıcı, 2005, s. 437) millî parkın, faunası da oldukça zengindir. Bölgede yaşayan birçok memeli hayvanın başlıcaları olarak tilki, kurt, karaca, kirpi, tavşan, porsuk, gelincik, yaban domuzu, boz ayı ve vaşak sayılabilir (Doğanay, 2003, s. 51). Türkiye'nin önemli kuş alanından birisi olarak da tanımlanan bölgede (Düzgüneş \& Demirel, 2013, ss. 4-5) atmaca, ağaçkakan, şahin, karga, kuzgun, bıldırcın, doğan, çulluk ve karatavuk gibi kuşlar da bulunmaktadır (Doğanay, 2003, s. 51).

Altındere Vadisi Millî Parkı'nın bir bölümünü de içeren ve Maçka İlçe merkezine doğru daha fazla alanı kapsayan, Sümela Manastırı kültürel mirası için nitelikli bir turizm strateji planı geliştirebilmek adına, nitelikli koruma ve sürdürülebilir koruma bölgelerinin ve kontrollü kullanım alanlarının tanımlandığı Sümela Manastırı Önerilen Doğal Sit Alanı, 31 Ocak 2018 tarihinde, T.C. Çevre ve Şehircilik Bakanlığı Trabzon Tabiat Varlıklarını Koruma Bölge Komisyonu tarafından kabul edilmiştir. Alan, T.C. Çevre ve Şehircilik Bakanlığı'nın 3 Ekim 2018 tarihli ve 173480 sayılı Olur'u ile Sümela-Altındere Vadisi Doğal Sit Alanı adı ile tescil edilmiştir (T.C. Çevre ve Şehircilik Bakanlığı, 2018).

\section{BULGULAR VE TARTIŞMA}

DML'de yer alan benzer örneklerin, dönemin inançsal faaliyetlerinin yayıldığı daha kompleks yapılar grubu durumunda, bir vadiye ya da bir yarımadaya yayılmış halde ele alındığı tespit edilmiştir. Benzer örneklerin, Sümela Manastırı'nda olduğu gibi yerleşim bölgelerinden uzak, ormanlık alanlar içerisinde, bir vadinin sarp kayalık yamaçlarına kuruldukları, doğal çevre ile bir bütün olarak karma miras kategorisinde ele alındıkları gözlemlenmiştir. Meteora ve Athos Dağı mirasları karma miras olarak, Kadişa Vadisi ve Tanrı'nın Sedirleri Ormanı mirası ise içerdiği doğal öğelerin yetersiz bulunması sonucu kültürel miras olarak DML'ye kabul edilmiştir. Sümela Manastırı zengin bir ekolojik sistemde yer alan ve eski dönemlerden itibaren Vazelon ve Kuştul Manastırları ile çeşitli bağlar kurmuş olan bir miras olarak ön plana çıkmaktadır. Vazelon ve Kuştul Manastırlarının bulunduğu doğal ve tarihî çevre, Sümela Manastırı ile ortaktır. Üç 
manastırın her biri farklı vadilere bakan yerlerde konumlanmış olsalar da her üç manastır da kesintiye uğramayan ormanlık bir alan içerisinde yer almaktadır.

Bu bağlamda gerek 1981 yılında doğal sit alanı, 1997 yılında doğal ve arkeolojik sit olarak tanımlanması ve gerek 1987 yılında millî park ilân edilen Altındere Vadisi ve 2018 yılında doğal sit alanı olarak tescil edilen Sümela-Altındere Vadisi Doğal Sit Alanı içerisinde yer alması sebebi ile Sümela Manastırı kültürel mirasının da, kurulduğu dönemde aktif halde ilişki içerisinde bulunduğu diğer manastırlar ve içerisinde yer aldığı doğal miras alanları ile birlikte karma miras şeklinde ele alınmasının, DML'deki benzer nitelikli mevcut miraslara bakılarak daha uygun olacağı anlaşılmaktadır. Ancak Vazelon, Kuştul ve Panagia Keramesta Manastırlarının bütünlük durumunda eksiklikler bulunmaktadır. Sümela Manastırı adaylık dosyasının daha bütüncül bir yaklaşımla ele alınabilmesi için ilgili restorasyon çalışmalarının tamamlanması gerekmektedir.

\section{SONUÇ}

Hristiyanlığın yayıldığı önemli coğrafyalar arasında bulunan Anadolu'da da diğer yakın coğrafyalarda olduğu gibi güvenlik ön planda tutulmuştur. Erişilmesi güç, fark edilmesi zor, ormanlık alanlarda suyun bulunduğu sarp kayalıklarda yer alan mağaralar içerisinde inançları doğrultusunda yaşamaya çalışan bir grup insanın kurduğu bu gibi manastırlar, yüzyıllar içerisinde yapılaşarak dünya mirasları olacak kadar gelişen kültürel varlıklar haline dönüşmüştür. UNESCO Dünya Miras Listesi'ne kayıtlı benzer örnekler incelendiğinde, birbirleri ile yakın ilişkilerde bulunan manastırların, doğal çevreleri ile birlikte ele alındığı daha bütüncül bir yaklaşımla Kalıcı Liste'ye tanımlandığı görülmektedir.

Türkiye UNESCO Geçici Listesi'nde yer alan Sümela Manastırı'nın Sümela-Altındere Vadisi Doğal Sit Alanı ve Altındere Vadisi Millî Parkı içerisinde bulunduğu, günümüzde Maçka İlçesi sınırları içerisinde kalan Vazelon ve Kuştul Manastırı ile birlikte ortak bir geçmişi paylaştığı görülmüştür. Sümela Manastırı kültürel mirasının gerek doğal miraslar içerisinde yer alması gerek tarihsel birlikteliği olan benzer özellikteki büyük manastırların yakın çevresindeki varlığı, yapılmış olan miras tanımının yeniden ele alınmasını gerektirmektedir. Miras alanının diğer iki büyük manastırı da kapsayacak şekilde genişletilerek doğal çevresi ile birlikte, karma miras statüsünde tanımlanması, UNESCO Dünya Miras Listesi'ndeki mevcut duruma daha uygun düşmektedir. Her üç büyük manastırın ve millî park ile doğal sit alanının tek yerel yönetim sınırları içerisinde kalması, alan yönetimi ve yönetim planı için ayrıca bir avantajdır. Bu gibi bütünleşik mirasların ülke ve yöre turizmine katkısının da daha fazla olacağı açıktır. Ancak Vazelon, Palegia Keramesta ve Kuştul Manastırları, UNESCO Dünya Miras Listesi'ne yönelik muhtemel bir adaylık durumunda yenileme ve onarım çalışmalarına ihtiyaç duyacaktır. Manastırlara yönelik bu tür çalışmaların hâlihazırda planlandığı bilinmektedir. Bu tür çalışmaların tamamlanmasını bekleyen bir yaklaşım bir miktar zaman istese de varlıkların birlikte ele alındığı bir mirasın getireceği faydalar düşünüldügünde bu beklenmesi gereken sürenin göze alınması daha uygun olacaktır. Aksi takdirde Vazelon, Palegia Keramesta ve Kuştul Manastırlarının bir dünya mirası olduklarını görmek için beklenmesi gereken süre, Türkiye UNESCO Geçici Listesi'nde kayıtlı miras sayısı da dikkate alındığında, çok daha fazla olacaktır.

\section{SUMMARY}

States parties to the UNESCO Convention on the Protection of the World Cultural and Natural Heritage are obliged to include in their UNESCO tentative list heritages they wish to 
inscribe on the UNESCO World Heritage List. Maps showing the boundaries of the property area and the buffer zone are one of the indispensable components of a candidate heritage file to be submitted to the UNESCO World Heritage Committee. A state party is nationally responsible for the protection of the determined heritage sites by law and other sanctions. In this study, recommendations are made for defining the property area and buffer zone of Sumela Monastery Cultural Heritage which was registered in the UNESCO Tentative List of Turkey in 2000, by examining property areas and buffer zones of heritages that have similar characteristics with Sumela Monastery in the UNESCO World Heritage List. Meteora (Hellenic Republic), Mount Athos (Hellenic Republic) and Ouadi Qadisha (the Holy Valley) and the Forest of the Cedars of God (Horsh Arz el-Rab) (Republic of Lebanon) are found as the similar examples. While Meteora and Mount Athos are in the mixed category, Ouadi Qadisha and the Forest of the Cedars of God are inscribed in the cultural category despite being presented in the mixed category. It is observed that a large-scale field definition was applied for the similar heritages in the List, including the natural environment they related to. When local potential is examined to define similar areas for Sumela Monastery, it is noticed that Maçka District, where the Sumela Monastery is located, also has similar natural heritages that are currently legally protected such as the Sümela-Altındere Valley Natural Protected Area and the Altındere Valley National Park and similar cultural heritages with similar or complementary architectural features such as Vazelon, Panagia Keramesta and Kuştul Monasteries and St. Barbara Chapel that were in interaction with Sumela Monastery in history. It is detected that defining the property area and buffer zone by covering the mentioned heritages would be more suitable for the current situation of the list. However, it is determined that the monasteries, which became idle after the Convention Concerning the Exchange of Greek and Turkish Populations in 1923, are in need of restoration and renovation to be included in the nomination dossier. Fortunately, it is announced that such works are already planned by the local authority. Although it may delay the inscription process, completion of restoration and renovation works will be more beneficial for the protection of Sumela Monastery and other neighbouring heritages in Maçka District at local, national and international levels.

Makale Bilgileri

\begin{tabular}{ll}
\hline Etik Kurul Kararı: & Etik Kurul Kararından muaftır. \\
Katılımcı Rızası: & Katılımcı Yok \\
Mali Destek: & $\begin{array}{l}\text { Çalışma için herhangi bir kurum ve projeden mali destek } \\
\text { alınmamışır. }\end{array}$ \\
Çıkar Çatışması: & $\begin{array}{l}\text { Çalışmada kişiler ve kurumlar arası çıkar çatışması } \\
\text { bulunmamaktadır. }\end{array}$ \\
Telif Hakları: & $\begin{array}{l}\text { Çalışmada kullanılan görsellerle ilgili telif hakkı } \\
\text { sahiplerinden gerekli izinler alınmıştır. }\end{array}$
\end{tabular}

Article Information

Ethics Committee Exempt from the Ethics Committee Decision.

Approval:

Informed Consent: No participant

Financial Support: No financial support from any institution or project.

Conflict of Interest: $\quad$ No conflict of interest.

Copyrights:

The required permissions have been obtained from the copyright holders for the images and photos used in the study. 


\section{KAYNAKÇA}

Aksu, Ö. V. (2015). Korunan doğal rekreasyon alanlarında donatı elemanlarının tasarımları: Altındere Vadisi Milli Parkı örneği. Kastamonu Üniversitesi Orman Fakültesi Dergisi, 15(2), 267-278.

Alikılıç, D. (2001). Tarih boyunca Trabzon havalisinde kütüphaneler. Atatürk Üniversitesi Türkiyat Araştırmaları Enstitüsü Dergisi, (17), 305-313.

Altun, L. (1995). Maçka (Trabzon) Orman İşletmesi ormanüstü serisinde orman yetiştirme ortamı birimlerinin ayrılması ve haritalanması üzerine araştırmalar (Doktora tezi). Erişim adresi: https://tez.yok.gov.tr/UlusalTezMerkezi/giris.jsp.

Anşin, R. (1978). Doğu Ladini traşlama alanlarında flora sorunu. Orman Mühendisliği Dergisi, (6), 38-40.

Atalay, İ. (1994). Türkiye vejetasyon coğrafyası. İzmir: Ege Üniversitesi Basım Evi.

Ayar, T. (2017). Osmanlı'nın son dönemi Maçka'da kiliselerin tamiri ve yeniden inşâsı. History Studies, 9(1), 1-19.

Başar, S. \& Bayram, A. (2018, 26 Mart). Sümela Manastırı'nda bugüne kadar görülmemişti... 'Çile odaları' bulundu. Hürriyet. Erişim adresi: https://www.hurriyet.com.tr/gundem/sumela-manastirinda-bugune-kadargorulmemisti-cile-odalari-gun-yuzune-cikariliyor-40784165.

BBC News (2010, 15 Ağustos). Sümela Manastırı'nda 88 yıl sonra ayin. Erişim adresi: https://www.bbc.com/turkce/haberler/2010/08/100815_sumela.

Bryer, A. \& Winfield, D. (1985). The Byzantine Monuments and Topography of the Pontos: Plates (C. 1). Washington: Dumbarton Oaks Research Library and Collection.

Bryer, A., Winfield, D., Ballance, S. \& Isaac, J. (2002). The Post-Byzantine Monuments of the Pontos: a source book. Aldershot, Hampshire: Ashgate Variorum.

Cagrisad (2012, 18 Ağustos). Kuştul Manastırı. Erişim adresi: http://wowturkey.com/forum/viewtopic.php?t=106075.

Coğrafî bilgi sistemi (2021). Erişim adresi: https://www.google.com/maps.

DHA (2018, 6 Mart). Vazelon Manastırı turizme kazandırılacak. TRTHaber. Erişim adresi: https://www.trthaber.com/haber/kultur-sanat/vazelon-manastiri-turizmekazandirilacak-353979.html.

Doğanay, S. (2003). Coğrafi özellikleri açısından Altındere Vadisi Milli Parkı. Doğu Coğrafya Dergisi, 8(10), 43-64.

Durmuş, A. (2016). Meryem Ana Manastırı. Uluslararası Türk Dünyası Kültür Araştırmaları Dergisi, (5), 93-117.

Düzgüneş, E. \& Demirel, Ö. (2013). Maçka Bölgesi'nin alternatif turizm potansiyeli açısından değerlendirilmesi. İnönü Üniversitesi Sanat ve Tasarım Dergisi, 3(7), 1-11.

Eyice, S. (1966). Trabzon yakınında Meryem Ana Manastırı. Belleten, 30(118), 243-264.

Eyice, S. (1991). Aynaroz. Türkiye Diyanet Vakfı İslâm Ansiklopedisi (C. 4, ss. 267-269) İstanbul: Türkiye Diyanet Vakfı Yayınları.

Eyice, S. (1996). One of the Most Visited Places in Trabzon: The Monastery of the Virgin Mary (or Sumela Monastery). H. Saltık (Ed.), Trabzon (G. Özer, Çev.) içinde (81-90). 
İstanbul: Türkiye Cumhuriyeti Kültür Bakanlığı - Renk Ajans Basım Yayın Hizmetleri Tic. Ltd. Şti.

Fallmerayer, J. P. (2002). Doğu'dan fragmanlar (1. bs., H. Salihoğlu, Çev.). İstanbul: İmge Kitabevi Yayınları.

Gümüş, C. \& Eryılmaz, A. Y. (2015). Altındere Vadisi Milli Parkı'nda yaşanan tahriplerin yasal ve yönetsel boyutları. D. Toksoy \& M. M. Bayramoğlu (Ed.), IV. Ormancilkta Sosyo-Ekonomik Sorunlar Kongresi Bildirileri içinde (s. 4-15). Trabzon: Karadeniz Teknik Üniversitesi, Orman Fakültesi, Orman Ekonomisi Anabilim Dalı.

Günday, A. F. H. (1960). Hayat ve hatıralarım. İstanbul: Çelikcilt Matbaası.

İEllada (2019, 29 Nisan). I istoría tou Agíou Georgíou Peristereóta stin Trapezoúnta. Erişim adresi: $\quad$ https://iellada.gr/istoria/i-istoria-toy-agioy-georgioy-peristereota-stintrapezoynta.

İHA (2018, 14 Ekim). Fener Rum Patriği Bartholomeos Sümela için Trabzon'a Geldi. Kanal 23. Erişim adresi: https://www.kanal23.com/haber/gundem/fener-rum-patrigibartholomeos-sumela-icin-trabzona-geldi-VQ9FCBhF.

Kılıçaslan, A. (1996). Trabzon Değirmendere havzasının turizm potansiyeli ve planlaması. Türk Coğrafya Dergisi, (31), 183-197.

Köse, İ. (2012). The Monastery of Soumela and ancient trade routes connected to it. Codrul Cosminului, 18(1), 7-28.

Köse, İ. \& Demciuc, V. M., (2014). Vazelon (St. John) Monastery of Maçka Trebizond. Codrul Cosminului, 20(1), 259-272.

Menteş, İ. (1992). Altındere Vadisi Ulusal Parkı uzun devreli gelişme plânlamasına yönelik araştırmalar (Basılmamış Yüksek Lisans Tezi), Karadeniz Teknik Üniversitesi Fen Bilimleri Enstitüsü, Trabzon.

Miller, W. (1926). Trebizond: The last Greek Empire of the Byzantine Era: 1204-1461. Chicago: Argonaut.

Nişanyan, S. \& Nişanyan, M. (2002). Herkesin bilmediği olağanüstü yerler. İstanbul: Boyut Yayın Grubu.

Orthodoxian News Agency (2019, 17 Ocak). Ótan erímose o Ai Giórgis ston Pónto. Erişim adresi: $\quad$ https://www.orthodoxianewsagency.gr/ieres-mones/ót $\alpha v-\varepsilon \varrho \eta ́ \mu \omega \sigma \varepsilon-o-\alpha \eta-$

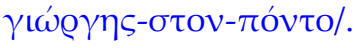

Rice, T. D. (1930). Notice on some religious buildings in the city and vilayet of Trebizond. Byzantion, 5(1), 47-81.

Sakıcı, Ç. (2005). Maçka Altındere Vadisi Milli Parkı'nın kaynak değerlerinin ve kullanımının rekreasyonel açıdan irdelenmesi. Korunan Doğal Alanlar Sempozyumu 2005 Bildirileri içinde (s. 435-442). Isparta: Süleyman Demirel Üniversitesi.

Şen, Ö. (1998). Trabzon tarihi. Trabzon: Derya Kitabevi.

Toksoy, D., Ayaz, H., Şen, G. \& Özden, S. (2005). Doğu Karadeniz Bölgesi'nde orman-köylü ilişkileri. Kafkas Üniversitesi Artvin Orman Fakültesi Dergisi, 6(1-2), 79-85.

Trabzon Turizm Müdürlügü (1993). Tarihi ve turistik değerleri ile Trabzon. Trabzon Turizm Müdürlüğü Yayınları/4.

Tüfek, Ö. (1978). The Monastery of Sumela (Meryemana) (I. Önalp, Çev.). Trabzon. 
Türkiye Cumhuriyeti Çevre ve Şehircilik Bakanlığ 12018, 09 Ekim). Trabzon İli, Maçka İlçesi, Sümela-Altındere Vadisi Doğal Sit Alanı Tescil İlanı. Tabiat Varlıklarını Koruma Genel Müdürlüğü. Erişim adresi: https://tvk.csb.gov.tr/trabzon-ili-macka-ilcesi-sumelaaltindere-vadisi-dogal-sit-alani-tescil-ilani-duyuru-363021.

Türkiye Cumhuriyeti Kültür ve Turizm Bakanlığı (2020a). Sümela Manastırı. Döner Sermaye İşletmesi Merkez Müdürlüğü, T.C. Kültür ve Turizm Bakanlığı'na bağlı müze ve ören yerlerinin giriş kontrol sistemleri ve genel olarak gişe hizmetlerinin modernizasyonu projesi. Erişim adresi: https://muze.gov.tr/muze-detay?SectionId=SML01\&DistId=MRK.

Türkiye Cumhuriyeti Kültür ve Turizm Bakanlığı (2020b). Kızlar Manastırı (Panagia Keramesta). Trabzon İl Kültür ve Turizm Müdürlüğü. Erişim adresi: https://trabzon.ktb.gov.tr/TR-57655/kizlar-manastiripanagia-keramesta.html.

Türkiye Cumhuriyeti Maçka Belediyesi (2020). Vazelon Manastırı. Erişim adresi: https://www.macka.bel.tr/turistik-bilgiler/vazelon-manastiri.

Türkiye Cumhuriyeti Tarım ve Orman Bakanlığı (2020a). Altındere Vadisi Milli Parkı /Sümela Manastırı. Doğa Koruma ve Milli Parklar Genel Müdürlüğü. Erişim adresi: http://altindere.tabiat.gov.tr/.

Türkiye Cumhuriyeti Tarım ve Orman Bakanlığı (2020b). Altındere Vadisi Milli Parkı. Erişim adresi: http://bolge12.ormansu.gov.tr/12bolge/altinderevadisimilliparki.aspx?sflang=tr.

Türkiye Cumhuriyeti Tarım ve Orman Bakanlığı (2020c). Milli Parklar. Doğa Koruma ve Milli Parklar Genel Müdürlüğü. Erişim adresi: https://www.tarimorman.gov.tr/DKMP.

UNESCO Dünya Miras Merkezi (2019). Operational Guidelines for the Implementation of the World Heritage Convention. Paris: World Heritage Centre.

UNESCO (2020). UNESCO Dünya Miras Merkezi resmî sitesi. Erişim adresi: https://whc.unesco.org/.

Yılmaz, D. O. (2015). Orta ve Doğu Karadeniz Bölgesi 19. yüzyıl Rum Ortodoks kiliseleri figürlü freskoları üzerine bir değerlendirme. Atatürk Üniversitesi Edebiyat Fakültesi Sosyal Bilimler Dergisi, (55), 127-167.

Yücel, E. (1988), Trabzon and Sumela. İstanbul: Net Turistik Yayınlar Sanayi ve Ticaret A.Ş.

Zaman, M. (2005). Türkiye'nin önemli inanç turizmi merkezlerinden biri: Sumela (Meryamana) Manastırı. Atatürk Üniversitesi Sosyal Bilimler Enstitüsü Dergisi, 6(2), 1-24. 